\title{
Permanent draft genome sequence of Vibrio tubiashii strain NCIMB 1337 (ATCC19106)
}

\author{
Ben Temperton ${ }^{1,2}$ and Simon Thomas ${ }^{1,2}$, Karen Tait ${ }^{1}$, Helen Parry ${ }^{1}$, Matt Emery ${ }^{3}$, Mike Allen ${ }^{1}$, \\ John Quinn", John MacGrath², Jack Gilbert ${ }^{1,4,5}$ \\ ${ }^{1}$ Plymouth Marine Laboratory, Prospect Place, The Hoe, Plymouth, UK \\ ${ }^{2}$ Queen's University Belfast, School of Biological Sciences, Medical Biology Centre, Belfast, \\ Northern Ireland \\ ${ }^{3}$ University of Plymouth, Department of Microbiology, Drakes Circus, Plymouth \\ ${ }^{4}$ Argonne National Laboratory, Argonne, IL, USA \\ ${ }^{5}$ Department of Ecology and Evolution, University of Chicago, Chicago, IL, USA
}

\begin{abstract}
Vibrio tubiashii NCIMB 1337 is a major and increasingly prevalent pathogen of bivalve mollusks, and shares a close phylogenetic relationship with both $V$. orientalis and $V$. coralliilyticus. It is a Gram-negative, curved rod-shaped bacterium, originally isolated from a moribund juvenile oyster, and is both oxidase and catalase positive. It is capable of growth under both aerobic and anaerobic conditions. Here we describe the features of this organism, together with the draft genome and annotation. The genome is 5,353,266 bp long, consisting of two chromosomes, and contains 4,864 protein-coding and 86 RNA genes.
\end{abstract}

\section{Introduction}

The genus Vibrio is both numerous and ubiquitous within marine environments, with Vibrio species harbored within many diverse marine organisms, such as mollusks, shrimps, fishes, cephalopods and corals [1]. Comparative genome analysis has revealed a huge genetic diversity within this genus, which is driven by mutations, chromosomal rearrangements, loss of genes by decay or deletion, and gene acquisitions through duplication or horizontal transfer (e.g. the acquisition of bacteriophages, pathogenicity islands, and superintegrons), the combination of which presumably stimulates genetic and functional diversity and allows this group to colonize a wide variety of ecological niches and hosts [1,2].

Vibrio tubiashii was first described as three strains of Vibrio anguillarum by Tubiash et al [3] in 1965. The organisms were isolated from bivalve mollusks during an outbreak of bacillary necrosis in Milford, Connecticut, and deposited in the American Type Culture Collection as ATCC 19105, 19106 and 19109. These three strains were further elucidated and formally named as $V$. tubiashii by Hada et al [4] in 1984. Subsequently, several virulence factors have been identified $[5,6]$ and the organism is increasingly implicated in major disease outbreaks in bivalve mollusks [1].
V. tubiashii is closely related to the proposed coral pathogen $V$. coralliilyticus, as well as $V$. orientalis, a bacterium associated with penaeid shrimps [7]. Indeed, $V$. coralliilyticus was initially designated as a $V$. tubiashii strain $[8,9]$ due to their close similarity.

\section{Classification and features}

Vibrio tubiashii 1337 belongs to the Gammaproteobacteria and are contained within the family, Vibrionaceae [Table 1]. Cells of Vibrio tubiashii are Gram-negative curved-rods of approximately 0.5 by $1.5 \mu \mathrm{m}$, which are motile in liquid media by means of a single sheathed, polar flagellum $[3,4]$ These cells are facultative anaerobes, $[3,4,22]$. It is catalase and oxidase positive, capable of splitting indole from tryptophan, and can use glucose, xylose, mannitol, rhamnose, sucrose, arabinose and acetate as sole carbon sources, and has $\beta$ galactosidase activity, despite an apparent inability to ferment lactose. V. tubiashii is capable of dissimilatory nitrate and nitrite reduction under anaerobic conditions, can use organic phosphorus during phosphate limitation, and can utilize 2aminoethylphosphonate as a sole phosphorus source. 
$V$. tubiashii has an absolute requirement for sodium and chloride ions, and is incapable of growth on media containing less than $0.5 \% \mathrm{~W} / \mathrm{V} \mathrm{NaCl}$. The temperature optimum for growth is $25^{\circ} \mathrm{C}$, but growth does occur in the range of $12-30^{\circ} \mathrm{C}$. The organism is killed at $37^{\circ} \mathrm{C}$. V. tubiashii has a biphasic $\mathrm{pH}$ response and grows optimally at both pH 8.0 and 6.5, but displays weakened growth at pH 7.0 and 7.5. The bacterium shows rapid growth on marine broth and produces buff colored, opaque, irregular, slightly convex colonies on marine agar, and yellow colonies, characteristic of the $\mathrm{Vi}$ brionaceae, on Thiosulfate-Citrate-Bile-Sucrose Agar (TCBS).

\section{Growth conditions and DNA isolation}

Vibrio tubiashii NCIMB 1337 (ATCC19106) was grown in marine broth (seawater $+1 \mathrm{gl}^{-1}$ yeast extract and $0.5 \mathrm{gl}^{-1}$ tryptone) at $25^{\circ} \mathrm{C}$ for 24 hours. DNA was extracted using the Qiagen DNAeasy blood and tissue kit, without modification of the manufacturer's protocol.

\section{Genome sequencing and annotation Genome sequencing}

The genome was sequenced using the Illumina sequencing platform. All general aspects of library construction and sequencing performed at the NERC Biomolecular analysis facility can be found on the NBAF website [23]. SOLEXA Illumina reads were assembled using VELVET Large Newbler contigs that were broken into 4,074 overlapping fragments of $1,000 \mathrm{bp}$ and entered into the assembly as pseudo-reads. The sequences were assigned quality scores based on consensus q-scores with modifications to account for overlap redundancy and to adjust inflated q-scores. The error rate of the completed genome sequence is less than 1 in 100,000. Overall sequencing provided $131 \times$ coverage of the genome.

\section{Genome annotation}

Genes were identified using the RAST server The predicted CDSs were translated and used to search the National Center for Biotechnology Information (NCBI) nonredundant database, UniProt, TIGRFam, Pfam, PRIAM, KEGG, COG, and InterPro databases. The tRNAScanSE tool [24] was used to find tRNA genes, whereas ribosomal RNAs were found by using BLASTn against the ribosomal RNA databases. The RNA components of the protein secretion complex and the RNaseP were identified by searching the genome for the corresponding Rfam profiles using INFERNAL [25]. Additional gene prediction analysis and manual functional annotation was performed within the Integrated Microbial Genomes (IMG) platform developed by the Joint Genome Institute, Walnut Creek, CA, USA [26,27].

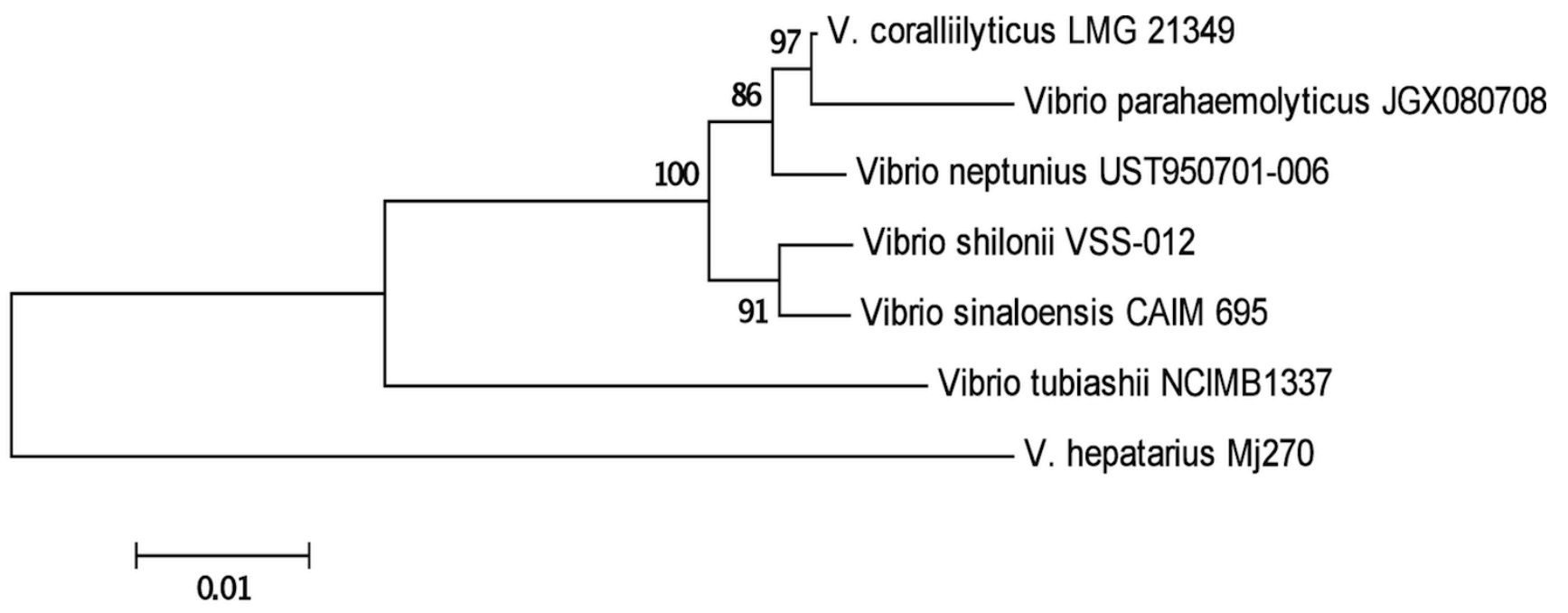

Figure 1. Phylogenetic tree highlighting the position of $V$. tubiashii NCIMB 1337 relative to other Vibrio strains. The tree was inferred from 1,159 aligned characters of the 16S rRNA gene sequence under the neighborhood joining criterion. Numbers above the branches are support values from 1,000 bootstrap replicates if greater than $60 \%$. 
Table 1. Classification and general features of $V$. tubiashii according to the MIGS recommendations

\begin{tabular}{|c|c|c|c|}
\hline MIGS ID & Property & Term & Evidence code \\
\hline & \multirow{7}{*}{ Current classification } & Domain Bacteria & TAS [10] \\
\hline & & Phylum Proteobacteria & TAS [11] \\
\hline & & Class Gammaproteobacteria & TAS $[12,13]$ \\
\hline & & Order Vibrionales & TAS [14] \\
\hline & & Family Vibrionaceae & TAS $[15,16]$ \\
\hline & & Genus Vibrio & TAS $[15,17-19]$ \\
\hline & & Species Vibrio tubiashii NCIMB 1337 & TAS [4] \\
\hline & Gram stain & negative & IDA \\
\hline & Cell shape & Curved rods (vibroid) & IDA \\
\hline & Motility & motile via single polar flagellum & IDA \\
\hline & Sporulation & Non-sporulating & IDA \\
\hline & Temperature range & Mesophile $12-30^{\circ} \mathrm{C}$ & IDA \\
\hline & Optimum temperature & $25^{\circ} \mathrm{C}$ & IDA \\
\hline MIGS 6.3 & Salinity & Slightly halophylic, optimum $1-3 \% \mathrm{NaCl}$ & IDA \\
\hline \multirow[t]{3}{*}{ MIGS-22 } & Oxygen requirement & Aerobic/ facultative anaerobic & IDA \\
\hline & Carbon source & Highly diverse & IDA \\
\hline & Energy source & Highly diverse & IDA \\
\hline MIGS-6 & Habitat & Marine invertebrates & TAS [20] \\
\hline MIGS-16 & Biotic relationship & Parasitic & TAS [3] \\
\hline \multirow[t]{2}{*}{ MIGS-14 } & Biosafety level & 2 & TAS [4] \\
\hline & Isolation & Moribund juvenile oyster (Crassostrea virginica) & TAS $[3,4]$ \\
\hline MIGS-4 & Geographical location & Milford, Connecticut, USA & TAS [3] \\
\hline MIGS-5 & Sample collection time & 01/02/1965 & TAS [3] \\
\hline MIGS 4.1 & latitude & $41.22 \mathrm{~N}$ & TAS [3] \\
\hline MIGS 4.2 & longitude & $-73.06 \mathrm{~W}$ & TAS [3] \\
\hline MIGS 4.3 & Depth & Not reported & \\
\hline MIGS 4.4 & Altitude & Marine & TAS [3] \\
\hline
\end{tabular}

Evidence codes - IDA: Inferred from Direct Assay (first time in publication); TAS: Traceable Author Statement (i.e., a direct report exists in the literature); NAS: Non-traceable Author Statement (i.e., not directly observed for the living, isolated sample, but based on a generally accepted property for the species, or anecdotal evidence). These evidence codes are from the Gene Ontology project [21]. If the evidence code is IDA, then the property was directly observed, for a live isolate by one of the authors, or an expert or reputable institution mentioned in the acknowledgements.

\section{Genome project information}

This organism was selected for sequencing on the basis of its increasing impact as a bivalve pathogen, and was funded by $i$-G Peninsula. The genome project is deposited in the IMG database and the complete genome sequence in GenBank (CP001643). Sequencing, finishing and annotation were performed by the GenePool Team at NERC Biomolecular Analysis Facility (NBAF) Edinburgh. A summary of the project information is shown in Table 2.

\section{Genomic properties}

The genome was assembled into 335 contigs and includes two circular chromosomes combining to give a total size of $5,353,266$ bp $(44.84 \%$ GC content). A total of 4,950 genes were predicted, 4,864 of which are protein-coding genes. $74.22 \%$ of protein coding genes were assigned to a putative function with the remaining annotated as hypothetical proteins. 658 protein coding genes belong to paralogous families in this genome corresponding to a gene content redundancy of $13.29 \%$. The properties and the statistics of the genome are summarized in Tables 3-5. 
Table 2. Project information

\begin{tabular}{lll}
\hline MIGS ID & Property & Term \\
\hline MIGS-31 & Finishing quality & Draft \\
MIGS-28 & Libraries used & Illumina \\
MIGS-29 & Sequencing platforms & Illumina SOLEXA GAIIx \\
MIGS-31.2 & Fold coverage & $131 \times$ \\
MIGS-30 & Assemblers & Velvet \\
MIGS-32 & Gene calling method & RAST \\
& Genome Database release & 181 \\
& Genbank ID & 866909 \\
& Genbank Date of Release & December 12, 2010 \\
& GOLD ID & Gi07317 \\
\hline
\end{tabular}

Table 3. Summary of genome*

\begin{tabular}{lr}
\hline Label & Size (Mb) \\
\hline Chromosome 1 & 3.4 \\
Chromosome 2 & 1.9 \\
\hline *Two chromosomes & with no plasmids. \\
\multicolumn{2}{l}{ Approximate chromosome size estimated } \\
by Pulse field gel electrophoresis
\end{tabular}

Table 4. Nucleotide content and gene count levels of the genome

\begin{tabular}{|c|c|c|}
\hline Attribute & Value & $\%$ of total ${ }^{2}$ \\
\hline Size (bp) & $5,353,266$ & $100 \%$ \\
\hline $\mathrm{G}+\mathrm{C}$ content $(\mathrm{bp})$ & $2,400,750$ & $44.87 \%$ \\
\hline Coding region (bp) & $4,627,782$ & $86.45 \%$ \\
\hline Total genes ${ }^{\mathrm{b}}$ & 4950 & $100 \%$ \\
\hline RNA genes & 86 & $1.74 \%$ \\
\hline Protein-coding genes & 4864 & $98.26 \%$ \\
\hline Genes in paralog clusters & 658 & $13.29 \%$ \\
\hline Genes assigned to COGs & 3674 & $74.22 \%$ \\
\hline Genes with signal peptides & 1655 & $33.43 \%$ \\
\hline Genes with transmembrane helices & 1167 & $23.58 \%$ \\
\hline Paralogous groups & 658 & $13.29 \%$ \\
\hline
\end{tabular}

a)The total is based on either the size of the genome in base pairs or the total number of protein coding genes in the annotated genome.

b)Also includes 54 pseudogenes and 5 other genes. 
Table 5. Number of genes associated with the 25 general COG functional categories

\begin{tabular}{lrrl}
\hline Code & Value & \%age & Description \\
\hline J & 200 & 4.86 & Translation \\
A & 1 & 0.02 & RNA processing and modification \\
K & 369 & 8.96 & Transcription \\
L & 154 & 3.74 & Replication, recombination and repair \\
B & 1 & 0.02 & Chromatin structure and dynamics \\
D & 37 & 0.9 & Cell cycle control, mitosis and chromosome partitioning \\
Y & & & Nuclear structure \\
V & 75 & 1.82 & Defense mechanisms \\
T & 432 & 8.31 & Signal transduction mechanisms \\
M & 227 & 5.51 & Cell wall/membrane biogenesis \\
N & 148 & 3.59 & Cell motility \\
U & 146 & 3.55 & Intracellular trafficking and secretion \\
O & 173 & 4.2 & Posttranslational modification, protein turnover, chaperones \\
C & 203 & 4.93 & Energy production and conversion \\
G & 248 & 6.02 & Carbohydrate transport and metabolism \\
E & 348 & 8.45 & Amino acid transport and metabolism \\
F & 105 & 2.55 & Nucleotide transport and metabolism \\
H & 159 & 3.86 & Coenzyme transport and metabolism \\
I & 119 & 2.89 & Lipid transport and metabolism \\
P & 188 & 4.57 & Inorganic ion transport and metabolism \\
Q & 77 & 1.77 & Secondary metabolites biosynthesis, transport and catabolism \\
R & 445 & 10.81 & General function prediction only \\
S & 356 & 8.65 & Function unknown \\
- & 1276 & 25.78 & Not in COGs \\
\hline & & & \\
\hline
\end{tabular}

a) The total is based on the total number of protein coding genes in the annotated genome.

\section{Genomic comparison}

Based on COG I.D the Vibrio tubiashii genome shows most similarity to the genome of $V$ coralliilyticus $\left(\mathrm{R}^{2}=0.96\right)$ and to $V$. orientalis $\left(\mathrm{R}^{2}=0.94\right)$, while showing less similarity to $V$. shilonii $\left(\mathrm{R}^{2}=\right.$ 0.86) [Table 6]. This is in contrast to the 16Sbased analysis shown in Figure 1. However, it should be noted that $16 \mathrm{~S}$ rRNA analysis often poorly discriminates vibrios due to low sequence heterogeneity in the $16 \mathrm{~S}$ gene [28].

\section{Regulatory systems}

The Vibrio tubiashii NCIMB 1337 genome contains multiple quorum sensing systems, most notably a luxM/N system which has two adjacent copies of the luxN gene. In addition, there is a luxS/PQ system, with the lux $\mathrm{P}$ and $\mathrm{Q}$ gene appearing consecutively. There is also a cqsA/S system. It is probable that these three systems converge on the phospho-relay transfer system encoded by the luxO/luxU/hapR genes. There are two additional lux genes (LuxT and LuxZ). The genome also contains the rpoN gene encoding for the sigma-54 factor, which may indicate the presence of the twocomponent phosphorylation-dephosphorylation cascade described in V. harveyi [29] (note: Vibrio harveyi is also known as Lucibacterium harveyi and Beneckea harveyi.). 
Table 6. Comparison of the genome of Vibrio tubiashii NCIMB 1337 with other sequenced Vibrios

\begin{tabular}{lcccc}
\hline Genome Name & $\begin{array}{c}\text { Vibrio coralliilyticus } \\
\text { ATCC BAA-450 }\end{array}$ & $\begin{array}{c}\text { Vibrio orientalis } \\
\text { CIP 102891 }\end{array}$ & $\begin{array}{c}\text { Vibrio shilonii } \\
\text { AK1 }\end{array}$ & $\begin{array}{c}\text { Vibrio tubiashii } \\
\text { NCIMB 1337 }\end{array}$ \\
\hline Genes & 5,144 & 4,297 & 5,438 & 4,950 \\
RNA & 122 & 128 & 78 & 86 \\
W/ Func Pred & 3,687 & 3185 & 3,517 & 4,062 \\
w/ Func Pred \% & $71.68 \%$ & $74.12 \%$ & $64.67 \%$ & $82.06 \%$ \\
Enzymes & 1,143 & 1,058 & 1,258 & 1,116 \\
Enzymes \% & $22.22 \%$ & $24.62 \%$ & $23.13 \%$ & $22.55 \%$ \\
KEGG & 1397 & 1,257 & 1,511 & 1,354 \\
KEGG \% & $27.16 \%$ & $29.25 \%$ & $27.79 \%$ & $27.35 \%$ \\
COG & 3815 & 3,302 & 4,093 & 3,674 \\
COG \% & $74.16 \%$ & $76.84 \%$ & $75.27 \%$ & $74.22 \%$ \\
Pfam & 4127 & 3,520 & 4,379 & 3,976 \\
Pfam \% & $81.92 \%$ & $80.53 \%$ & $80.32 \%$ \\
TIGRfam & $1,23 \%$ & 1,515 & 1,708 & 1,651 \\
TIGRfam \% & 1,643 & $35.26 \%$ & $31.41 \%$ & $33.35 \%$ \\
Signal peptide & $31.94 \%$ & 1,408 & 1,214 & 1,655 \\
Signal peptide $\%$ & 1,733 & $32.77 \%$ & $22.32 \%$ & $33.43 \%$ \\
TransMb & $33.69 \%$ & 1,018 & 1,326 & 1,167 \\
TransMb Perc & 1,227 & $23.69 \%$ & $24.38 \%$ & $23.58 \%$ \\
Pfam Clusters & $23.85 \%$ & 2,091 & 2,163 & 2,186 \\
COG Clusters & 2,183 & 1,943 & 2,087 & 2,041 \\
TIGRfam Clusters & 2,030 & 1,246 & 1,300 & 1,323 \\
GC Perc & 1,310 & 0.45 & 0.44 & 0.45 \\
Bases & 0.46 & 4698244 & $5,701,826$ & $5,353,266$ \\
\hline
\end{tabular}

\section{Antibiotic resistance}

There are six separate genes encoding for putative $\beta$-lactamases within the genome, but only two have homology at the protein levels with any know Vibrio $\beta$-lactamases. There is also a multiantibiotic resistance protein MarC, associated with an operon containing a variety of multidrug resis-

\section{Acknowledgements}

We wish to thank i-G Peninsula (Prospect Place, the Hoe, Plymouth, Devon, UK) for providing funding for

\section{References}

1. Thompson FL, lida T, Swings J. "Biodiversity of vibrios.," Microbiology and molecular biology reviews. [Table of contents]. Microbiol Mol Biol Rev 2004; 68:403-431. PubMed doi:10.1128/MMBR.68.3.403-431.2004

2. Colwell RR, Huq A. Environmental Reservoir of Vibrio cholerae The Causative Agent of Cholera. Ann N Y Acad Sci 1994; 740:44-54. PubMed doi:10.1111/j.1749-6632.1994.tb19852.x

3. Tubiash HS, Chanley PE, Leifson E. Bacillary necrosis, a disease of larval and juvenile bivalve tance proteins. This operon is controlled by a MerR type transcriptional regulator, which is often associated with antibiotic resistance [30], and may account for the kanamycin resistance observed in this strain by the authors.

this project, and NBAF Edinburgh for performing the sequencing.

mollusks. I. Etiology and epizootiology. J Bacteriol 1965; 90:1036-1044. PubMed

4. Hada HS, West PA, Lee JV, Stemmler J, Colwell RR. Vibrio tubiashii sp. nov., a Pathogen of Bivalve Mollusks. Int J Syst Bacteriol 1984; 34:1-4. doi:10.1099/00207713-34-1-1

5. Beaubrun JJG, Kothary MH, Curtis SK, Flores NC, Eribo BE, Tall BD. Isolation and characterization of Vibrio tubiashii outer membrane proteins and determination of a toxR homolog. Appl Environ Microbiol 2008; 74:907-911. PubMed doi:10.1128/AEM.02052-07 
Temperton et al.

6. Kothary $\mathrm{MH}$, Delston RB, Curtis SK, McCardell BA, Tall BD. Purification and characterization of a vulnificolysin-like cytolysin produced by Vibrio tubiashii. Appl Environ Microbiol 2001; 67:37073711. PubMed doi:10.1128/AEM.67.8.3707$\underline{3711.2001}$

7. Abraham T. Distribution of luminous bacteria in semi-intensive penaeid shrimp hatcheries of Tamil Nadu, India. Aquaculture 2004; 232:81-90. doi:10.1016/S0044-8486(03)00485-X

8. Beaubrun JJG, Kothary MH, Curtis SK, Flores NC, Eribo BE, Tall BD. Isolation and characterization of Vibrio tubiashii outer membrane proteins and determination of a toxR homolog. Appl Environ Microbiol 2008; 74:907-911. PubMed doi:10.1128/AEM.02052-07

9. Ben-Haim Y, Zicherman-Keren M, Rosenberg E. Temperature-Regulated Bleaching and Lysis of the Coral Pocillopora damicornis by the Novel Pathogen Vibrio coralliilyticus. App/ Environ Microbiol 2003; 69:4236-4242. PubMed doi:10.1128/AEM.69.7.4236-4242.2003

10. Woese CR, Kandler O, Wheelis ML. Towards a natural system of organisms: proposal for the domains Archaea, Bacteria, and Eucarya. Proc Natl Acad Sci USA 1990; 87:4576-4579. PubMed doi:10.1073/pnas.87.12.4576

11. Garrity GM, Holt JG. The Road Map to the Manual. In: Garrity GM, Boone DR, Castenholz RW (eds), Bergey's Manual of Systematic Bacteriology, Second Edition, Volume 1, Springer, New York, 2001, p. 119-169.

12. List Editor. Validation of publication of new names and new combinations previously effectively published outside the IJSEM. List no. 106. Int J Syst Evol Microbiol 2005; 55:2235-2238. doi:10.1099/ijs.0.64108-0

13. Garrity GM, Bell JA, Lilburn T. Class III. Gammaproteobacteria class. nov. In: Garrity GM, Brenner DJ, Krieg NR, Staley JT (eds), Bergey's Manual of Systematic Bacteriology, Second Edition, Volume 2, Part B, Springer, New York, 2005, p. 1.

14. Garrity GM, Holt JG. Taxonomic Outline of the Archaea and Bacteria. In: Garrity GM, Boone DR, Castenholz RW (eds), Bergey's Manual of Systematic Bacteriology, Second Edition, Volume 1, Springer, New York, 2001, p. 155-166.

15. Skerman VBD, McGowan V, Sneath PHA. Approved Lists of Bacterial Names. Int / Syst Bacteriol 1980; 30:225-420. doi:10.1099/00207713$\underline{30-1-225}$
16. Véron M. La position taxonomique des Vibrio et de certaines bactéries comparables. C R Acad Sci Hebd Seances Acad Sci 1965; 261:5243-5246.

17. Pacini F. Osservazione microscopiche e deduzioni patologiche sul cholera asiatico. Gazette Medicale de Italiana Toscano Firenze 1854; 6:405412.

18. Shewan J, Veron M. Genus I. Vibrio Pacini 1854, 411. In: Buchanan RE, Gibbons NE (eds), Bergey's Manual of Determinative Bacteriology, Eighth Edition, The Williams and Wilkins Co., Baltimore, 1974, p. 340-345.

19. Judicial Commission. Opinion 31. Conservation of Vibrio Pacini 1854 as a Bacterial Generic Name, Conservation of Vibrio cholerae Pacini 1854 as the Nomenclatural Type Species of the Bacterial Genus Vibrio, and Designation of Neotype Strain of Vibrio cholerae Pacini. Int Bull Bacteriol Nomencl Taxon 1965; 15:185-186. doi:10.1099/00207713-15-3-185

20. Hada HS, West PA, Lee JV, Stemmler J, Colwell RR. Vibrio tubiashii sp. nov., a Pathogen of Bivalve Mollusks. Int J Syst Bacteriol 1984; 34:1-4. doi:10.1099/00207713-34-1-1

21. Ashburner M, Ball CA, Blake JA, Botstein D, Butler H, Cherry JM, Davis AP, Dolinski K, Dwight SS, Eppig JT, et al. Gene Ontology: tool for the unification of biology. Nat Genet 2000; 25:25-29. $\underline{\text { PubMed }} \underline{\underline{\text { doi:10.1038/75556 }}}$

22. Pillidge CJ, Colwell RR. Nucleotide sequence of the $5 \mathrm{~S}$ rRNA from Listonella (Vibrio) ordalii ATCC 33509 and Listonella (Vibrio) tubiashii ATCC 19105. Nucleic Acids Res 1988; 16:3111. PubMed doi:10.1093/nar/16.7.3111

23. NBAF website. http://nbaf.nerc.ac.uk

24. Lowe TM, Eddy SR. tRNAscan-SE: a program for improved detection of transfer RNA genes in genomic sequence. Nucleic Acids Res 1997; 25:955-964. PubMed doi:10.1093/nar/25.5.955

25. INFERNAL http://infernal.janelia.org

26. Markowitz VM, Korzeniewski F, Palaniappan K, Szeto E, Werner G, Padki A, Zhao X, Dubchak I, Hugenholtz P, Anderson I, et al. The Integrated Microbial Genomes (IMG) system. Nucleic Acids Res 2006; 34:D344-D348. PubMed doi:10.1093/nar/gkj024

27. The DOE Joint Genome Institute. http://img.jgi.doe.gov

28. Thompson FL, Gevers D, Thompson CC, Dawyndt P, Naser S, Hoste B, Munn CB, Swings J. 
Phylogeny and molecular identification of vibrios on the basis of multilocus sequence analysis. Appl Environ Microbiol 2005; 71:5107-5115. PubMed doi:10.1128/AEM.71.9.5107-5115.2005

29. Lilley BN, Bassler BL. Regulation of quorum sensing in Vibrio harveyi by LuxO and sigma-54. Mol
Microbiol 2000; 36:940-954. PubMed doi:10.1046/j.1365-2958.2000.01913.x

30. Brown NL, Stoyanov JV, Kidd SP, Hobman JL. The MerR family of transcriptional regulators. FEMS Microbiol Rev 2003; 27:145-163. PubMed doi:10.1016/S0168-6445(03)00051-2 